\title{
Histamine formation in flying fish contaminated with Staphylococcus xylosus
}

\author{
Hsien-Feng Kung • Yi-Chen Lee • Ya-Ling Huang • Chun-Yung Huang • \\ Chiu-Chu Hwang $\cdot$ Yung-Hsiang Tsai
}

Received: 3 April 2016/Accepted: 23 June 2016/Published online: 29 June 2016

(C) The Author(s) 2016. This article is published with open access at Springerlink.com

\begin{abstract}
Histamine is the main causative agent of scombroid poisoning. However, unlike scombroid fish, histamine poisoning due to consumption of flying fish has never been reported. In this study, the white muscle of flying fish had high levels of free histidine at approximately $423.9 \mathrm{mg} / 100 \mathrm{~g}$, and was inoculated with Staphylococcus xylosus Q2 isolated from dried flying fish at $5.0 \log \mathrm{CFU} / \mathrm{g}$ and stored at -20 to $35^{\circ} \mathrm{C}$ to investigate histamine-related quality. The histamine contents quickly increased to higher than $50 \mathrm{mg} / 100 \mathrm{~g}$ in samples stored at 25 and $35^{\circ} \mathrm{C}$ within $12 \mathrm{~h}$ as well as stored at $15^{\circ} \mathrm{C}$ within $48 \mathrm{~h}$. However, bacterial growth and histamine formation were controlled by cold storage of the samples at $4^{\circ} \mathrm{C}$ or below. Once the frozen flying fish samples stored at $-20^{\circ} \mathrm{C}$ for 2 months were thawed and stored at $25^{\circ} \mathrm{C}$ after $24 \mathrm{~h}$, histamine started to accumulate rapidly ( $>50 \mathrm{mg} / 100 \mathrm{~g}$ of fish). Therefore, flying fish muscle was a good substrate for histamine formation by bacterial histidine decarboxylation at elevated temperatures $\left(>15^{\circ} \mathrm{C}\right)$ when it is contaminated with S. xylosus. In conclusion, since the improperly contaminated flying fish muscle with $S$. xylosus could lead to production of hazardous levels of histamine over time when stored at temperatures $>15^{\circ} \mathrm{C}$, the flying fish should be stored below $4{ }^{\circ} \mathrm{C}$ or below to control proliferation of S. xylosus, and TVBN and histamine production.
\end{abstract}

Keywords Histamine $\cdot$ Flying fish $\cdot$ Histamine-forming bacteria $\cdot$ Staphylococcus xylosus

\section{Introduction}

Histamine is the causative agent of scombroid poisoning and a foodborne chemical hazard. Although scombroid poisoning is usually a mild illness with symptoms, including rash, urticaria, nausea, vomiting, diarrhea, flushing, tingling, and itching of the skin (Hungerford 2010), the severity of the illness varies considerably depending on the amounts of histamine ingested and individual's susceptibility to histamine. Scombroid fish, such as tuna, mackerel, bonito, and saury that contain high levels of free histidine in their

\section{H.-F. Kung}

Department of Biotechnology, Tajen University, Pingtung, Taiwan, R.O.C

Y.-C. Lee · Y.-L. Huang · C.-Y. Huang · Y.-H. Tsai ( $ه)$

Department of Seafood Science, National Kaohsiung Marine University, No. 142, Hai-Chuan Rd. Nan-Tzu, Kaohsiung 811, Taiwan, R.O.C

e-mail: yhtsai01@seed.net.tw

C.-C. Hwang

Department of Hospitality Management, Yu Da University of Science and Technology, Zaoqiao City, Miaoli, Taiwan, R.O.C 
muscle, are often implicated in scombroid poisoning (Hungerford 2010). However, several species of nonscombroid fish, such as mahi-mahi, marlin, herring, and sardine, can also be implicated in scombroid poisoning (Lehane and Olley 2000). In Taiwan, scombroid poisoning occurs occasionally and has commonly been associated with swordfish, marlin, tuna, mackerel, and milkfish (Chang et al. 2008; Chen et al. 2008, 2010; Tsai et al. 2005a; Lee et al. 2016).

High levels of histamine accumulation are found in scombroid fish muscle by proliferation of bacteria synthesizing histidine decarboxylase to convert free histidine to histamine (Rawles et al. 1996). These bacteria have been isolated not only from fish and other seafood products but also from other types of foods, such as cheese, fermented vegetable, and wine (Taylor 1986). Two enzymes families of histidine decarboxylase have been distinguished based on the cofactor used: the pyridoxal-5'-phosphate-dependent and the pyruvoyl-dependent, being their sequences and characteristics radically different. Pyridoxal-5'-phosphate-dependent histidine decarboxylases have been identified from Gram-negative enteric bacteria: Morganella morganii, Raoutella ornithinolytica, and Enterobacter aerogenes, isolated from fish (Vaaler et al. 1986). On the other hand, the pyruvoyl-dependent histidine decarboxylases have been found in Gram-positive bacteria: Lactobacillus 30a, Clostridium perfringens, Lactobacillus buchneri, and Staphylococcus spp. isolated from cheese, wine and salted fish products (van Poelje and Snell 1990; Hsu et al. 2009). Since histamine is a competitive inhibitor of the pyruvoyl-dependent enzymes but not of the pyridoxal-5'-phosphate-dependent enzymes (Vaaler et al. 1986), Gram-negative enteric histamine formers synthesizing pyridoxal-5'-phosphate-dependent enzymes are frequently isolated from fish, thus making it possible to accumulate histamine in fish muscle without inhibiting histidine decarboxylase activity. Consequently, these Gram-negative histamine formers can proliferate and synthesize histidine decarboxylase at elevated temperature $\left(>15{ }^{\circ} \mathrm{C}\right)$ and lead to histamine accumulation in tuna, sailfish, and milkfish muscles (Kim et al. 2002; Tsai et al. 2005b). On the other hand, there exits no report on the proliferation and histamine accumulation of Gram-positive histamine formers (such as Staphylococcus spp.) at elevated temperature in fish muscles.

Flying fish are important traditional fisheries resources in various Caribbean, South East Asian, and Southern Pacific regions and countries (Huang and Ou 2012). In the past, flying fish were economically important species for coastal fisheries, with the catch amount reaching the top twenty in terms of fisheries production in Taiwan. Darkwinged flying fish (Cypselurus cyanopyerus), Limpidwing flying fish (Cheilopogon unicolor), Spotwing flying fish (Cypselurus poecilopterus), and Stained flying fish (Cheilopogon spilonotopterus) are the main edible species caught in Taiwan (Huang and Ou 2012). Recently, Staphylococcus xylosus strain Q2 isolated from dried flying fish was a halotolerant histamine-former capable of producing $>500 \mathrm{ppm}$ of histamine in culture broth without shaking at $35^{\circ} \mathrm{C}$ for $24 \mathrm{~h}$ (Kung et al. 2015). So far, flying fish have never been implicated in the outbreaks of scombroid poisoning in the world. However, if the flying fish muscle is contaminated with Gram-positive histamine former, such as S. xylosus, and stored at improper temperatures, it is important to be aware that flying fish muscle could become a hazardous food vehicle for histamine poisoning. Currently, no information is available concerning histamine formation in contaminated flying fish muscle. This work was undertaken to study the effect of $S$. xylosus proliferation in flying fish muscle on histamine formation and total volatile basic nitrogen (TVBN) under the controlled storage temperatures of $-20,4,15,25$, and $35^{\circ} \mathrm{C}$.

\section{Materials and methods}

\section{Staphylococcus xylosus strain}

Strain of S. xylosus Q2 previously isolated from dried flying fish product sold in the retail markets of Taiwan was used (Kung et al. 2015). To confirm histamine production capability, the bacterial isolate was inoculated into tryptic soy broth (TSB, Difco, Becton-Dickinson, Sparks, MD, USA) supplemented with $1 \%$ histidine, and incubated at $35^{\circ} \mathrm{C}$ for $24 \mathrm{~h}$. The histamine content of $508 \mathrm{ppm}$ was then detected in the culture broth in duplicate using the HPLC method of Chen et al. (2010). The bacterium was grown on trypticase soy agar (Difco) slant, stored in a refrigerator $\left(4^{\circ} \mathrm{C}\right)$, and transferred to a fresh TSA slant every month. One loop of the bacterial culture (TSA slant) was inoculated into TSB and incubated at $35^{\circ} \mathrm{C}$ for $18 \mathrm{~h}$. One milliliter of the enriched culture was serially diluted in $0.1 \%$ peptone water, and $0.1 \mathrm{~mL}$ aliquots of the diluted culture were 
spread on aerobic plate count (APC) agar (Difco) containing $0.5 \% \mathrm{NaCl}$. Bacterial colonies were counted after the plates were incubated at $35{ }^{\circ} \mathrm{C}$ for $24 \mathrm{~h}$. The enriched culture was stored at $7{ }^{\circ} \mathrm{C}$ before being used for sample inoculation. Based on the colony counts obtained, the enriched culture stored at $7{ }^{\circ} \mathrm{C}$ for $24 \mathrm{~h}$ was then serially diluted with $0.1 \%$ peptone water to obtain a culture suspension with the desired concentration. To reconfirm and ensure no increase in bacterial counts in enriched culture stored $7{ }^{\circ} \mathrm{C}$ after $24 \mathrm{~h}$, one milliliter of the enriched culture stored $7{ }^{\circ} \mathrm{C}$ after $24 \mathrm{~h}$ was serially diluted in $0.1 \%$ peptone water, and $0.1 \mathrm{~mL}$ aliquots of the diluted culture were spread on APC agar described by above method.

Flying fish white muscle and storage conditions

Fresh flying fish (Cypselurus poecilopterus) kept in ice at retail stores was obtained from a local seafood market in Hengchun Township, Pingtung County, Taiwan. The fish wrapped in aseptic bags was placed in ice, and transported to the laboratory immediately. The white muscle in dorsal parts of the flying fish was aseptically cut in a vertical laminar flow hood. After the white muscle of flying fish was washed with ethanolacetone $(1: 1, \mathrm{v} / \mathrm{v})$ to kill the microflora on the surface of fish muscle and rinsed with sterile water to avoid the ethanol-acetone residue (Tsai et al. 2005a), it was placed in a sterile food processor, ground to mince, and mixed with diluted culture suspension of $S$. xylosus by blending at low speed to prepare a contamination level of $1 \times 10^{5} \mathrm{CFU} / \mathrm{g}$ for studies. The inoculated samples were then aseptically transferred to sterile polyethylene bags $(30 \mathrm{~g} / \mathrm{bag})$ and stored at $-20,4,15,25$, and $35^{\circ} \mathrm{C}$. Growth of S. xylosus and formation of TVBN and histamine were monitored at $6,12,24$, and $48 \mathrm{~h}$ for samples stored at 25 and $35^{\circ} \mathrm{C}$. For samples stored at 4 and $15^{\circ} \mathrm{C}$, analyses were performed every $24 \mathrm{~h}$ for $4 \mathrm{~d}$. Fish samples that were stored at $-20^{\circ} \mathrm{C}$ were analyzed for bacterial loads at 1, 2, 3, 4, and 8 weeks. All analyses were conducted in triplicate for each sampling time. Results were reported as means of triplicate determinations.

In another study to determine if frozen storage at $-20^{\circ} \mathrm{C}$ would kill the inoculated S. xylosus and prohibit TVBN and histamine formation, fish samples that had been stored at $-20^{\circ} \mathrm{C}$ for 8 weeks were thawed and then transferred to storage at $25^{\circ} \mathrm{C}$. The fish samples were analyzed at $6,12,24$, and $48 \mathrm{~h}$.

Free amino acids analysis of white muscle in flying fish

Free amino acids (FAAs) in white muscle of flying fish were determined according to the method described by Konosu, Watanabe, and Shimizu (1974) in triplicate. Ten grams of sample was homogenized for 2 min in $20 \mathrm{~mL}$ of $7 \%$ trichloroacetic acid (TCA) and analyzed by postcolumn derivatization with ninhydrin using an L-8500 high-speed amino acid analyzer attached with Hitachi 2622 SC packed column $(4.6 \times 60 \mathrm{~mm}$; Hitachi, Tokyo, Japan). The buffers used were the standard lithium citrate buffers. Postcolumn derivatization with ninhydrin yielded amino acid derivatives which were measured by the absorbance at 570 and $440 \mathrm{~nm}$. Analytical conditions and procedures were performed according to the manual provided by the manufacturer (Hitachi, Ltd., Tokyo, Japan). The contents of the FAA in a sample were estimated on the basis of peak area of known concentrations of standards (Wako, Osaka, Japan) using Hitachi D-2850 Chromato Integrator.

Microbiological analysis

Ten grams of minced flying fish muscle was taken from each sterile polyethylene bag and homogenized at high speed for $2 \mathrm{~min}$ in a sterile blender (Osterizer, Madrid, Spain) with $90 \mathrm{ml}$ of $0.1 \%$ peptone water. The homogenate was serially diluted with $0.1 \%$ peptone water, and $0.1-\mathrm{mL}$ aliquots of the diluted sample were plated on aerobic plate count (APC) agar (Difco) containing $0.5 \% \mathrm{NaCl}$ in duplicate. Bacterial colonies were counted after the plates were incubated at $35^{\circ} \mathrm{C}$ for 2 days.

Determination of total volatile basic nitrogen (TVBN)

TVBN increase is related to the activity of spoilage bacteria and endogenous enzymes in fish. The action of such enzymes results in the formation of compounds, including ammonia $\left(\mathrm{NH}_{3}\right)$, dimethylamine (DMA), and trimethylamine (TMA) (Ozogul et al. 2004). Therefore, TVBN, including $\mathrm{NH}_{3}$, DMA and TMA, can be considered as a quality index for fish. The TVBN contents of each flying fish muscle sample were measured by 
the method of Conway's dish (Cobb et al. 1973). The TVBN extract of each sample in $6 \%$ trichloroacetic acid (TCA, Sigma, St. Louis, Missouri) was absorbed by boric acid and then titrated with $0.02 \mathrm{~N} \mathrm{HCl}$. Results of TVBN contents were expressed as $\mathrm{mg} / 100 \mathrm{~g}$ fish.

Analysis of histamine

Five grams of minced flying fish muscle was transferred to a 50-mL centrifuge tube and homogenized (Omni International Waterbury) with $20 \mathrm{~mL}$ of $6 \%$ TCA for $3 \mathrm{~min}$. The homogenate was centrifuged at $10,000 \times g$ for $10 \mathrm{~min}\left(4^{\circ} \mathrm{C}\right)$ (Hitachi, SCR20B) and filtered through a Whatman No.2 filter paper (Whatman, Maldstone, England). The sample filtrate was collected in a volumetric flask and mixed with $6 \%$ TCA to a final volume of $50 \mathrm{~mL}$. Each sample extract $(1 \mathrm{~mL})$ and histamine standards $(0.5,1.0$, and $1.5 \mu \mathrm{g})$ were derivatized with dansyl chloride according to the previously described method (Chen et al. 2010). The dansyl derivatives were dissolved in $5 \mathrm{ml}$ acetonitrile, and an aliquot of $20 \mu \mathrm{L}$ was used for histamine analysis with a Hitachi liquid chromatography (Hitachi, Tokyo, Japan) consisting of a Model L-6200 pump, a Rheodyne Model 7125 syringe loading sample injector, a Model L-4000 UV-Vis detector (set at $254 \mathrm{~nm}$ ), and a Model D-2500 Chromato Integrator. A Lichrospher 100 RP-18 reversed-phase column $(5 \mu \mathrm{m}, 125 \times 4.6 \mathrm{~mm}$, E. Merck, Damstadt, Germany) was used for separation. The gradient elution program began with 50:50 (v/v) acetonitrile:water at a flow rate of $1.0 \mathrm{~mL} / \mathrm{min}$ for $19 \mathrm{~min}$, followed by a linear increase to $90: 10$ acetonitrile:water $(1.0 \mathrm{~mL} / \mathrm{min})$ in the next $1.0 \mathrm{~min}$. The acetonitrile:water mix was then decreased to $50: 50(1.0 \mathrm{~mL} /$ min) during the next $10 \mathrm{~min}$. All samples were analyzed in duplicate.

Statistical analysis

Results were analyzed by analysis of variance (ANOVA) and Duncan's multiple range test. Significances between means of treatments were established at a value of $P<0.05$.

Table 1 Free amino acids content in white muscle of flying fish

\begin{tabular}{lcr}
\hline Free amino acids & Concentration $(\mathrm{mg} / 100 \mathrm{~g})$ & Percentage $(\%)$ \\
\hline Alanine & $13.4 \pm 3.6^{\mathrm{a}}$ & 2.30 \\
Aspartic acid & $1.2 \pm 0.5$ & 0.21 \\
Arginine & $2.6 \pm 1.0$ & 0.45 \\
Cystathionine & $4.6 \pm 1.6$ & 0.79 \\
Glutamic acid & $9.3 \pm 1.8$ & 1.60 \\
Glycine & $11.5 \pm 1.4$ & 1.97 \\
Histidine & $423.9 \pm 40.1$ & 72.72 \\
Leucine & $3.6 \pm 0.4$ & 0.62 \\
Isoleucine & $2.3 \pm 0.7$ & 0.39 \\
Lysine & $9.6 \pm 2.5$ & 1.65 \\
Methionine & $2.0 \pm 0.4$ & 0.34 \\
Phenylalanine & $2.6 \pm 1.1$ & 0.45 \\
Phosphoserine & $0.6 \pm 0.2$ & 0.10 \\
Proline & $23.4 \pm 4.6$ & 4.01 \\
Serine & $5.5 \pm 0.9$ & 0.94 \\
Taurine & $41.9 \pm 2.5$ & 7.19 \\
Threonine & $5.5 \pm 1.2$ & 0.94 \\
Tyrosine & $6.8 \pm 0.9$ & 1.17 \\
Valine & $12.6 \pm 3.0$ & 2.16 \\
Total & $582.9 \pm 95.7$ & 100 \\
\hline
\end{tabular}

a Mean \pm standard deviation $(n=3)$ 


\section{Results and discussion}

Free amino acids in white muscle of flying fish

The total contents of free amino acids (FAAs) in white muscle of flying fish are shown in Table 1. The total FAAs in white muscle of flying fish were $582.9 \mathrm{mg} / 100 \mathrm{~g}$ with histidine $(423.9 \mathrm{mg} / 100 \mathrm{~g})$, taurine $(41.9 \mathrm{mg} /$ $100 \mathrm{~g})$, and proline $(23.4 \mathrm{mg} / 100 \mathrm{~g})$ being the major three FAAs and accounting for $83.92 \%$ of the total FAAs. Among them, histidine at $423.9 \mathrm{mg} / 100 \mathrm{~g}$ is the most prominent free amino acid (FAA) found in the white muscle of flying fish, accounting for $72.72 \%$ of the total FAAs in this fish. Except for histidine, taurine, and proline, the other FAAs were found only a small amounts $(<13.4 \mathrm{mg} / 100 \mathrm{~g}$, or $<2.3 \%)$ in white muscle of flying fish. Histidine has been reported to function as a chemical buffer in migratory red-fleshed fish muscle when fish move vigorously, resulting in accumulation of acidic end products during the period of anaerobic metabolism (Konosu et al. 1974). Hibiki and Simidu (1959) reported a histidine level of $1010 \mathrm{mg} / 100 \mathrm{~g}$ in bigeye tuna. However, free histidine content in white muscle ranged from 870 to $1039 \mathrm{mg} / 100 \mathrm{~g}$ in yellowfin tuna (Antoine et al. 2001). With skipjack tuna, free histidine contents are detected at $1389 \mathrm{mg} / 100 \mathrm{~g}$ in the white muscle (Abe 1983). Mackerel contained $726 \mathrm{mg} / 100 \mathrm{~g}$ of free histidine in white muscle (Arnold and Brown 1978). Unlike those scombroid fish muscle samples tested above, the flying fish muscle tested in this study contains a lower level of free histidine $(423.9 \mathrm{mg} / 100 \mathrm{~g})$ in this study. It is known that the contents of free histidine in fish muscles can vary considerably due to differences in fish species, feeding, season, sex, and stage of maturity (Antoine et al. 1999). Bacterial histamine formation is affected by free histidine contents in fish muscle, serving as a substrate for histidine decarboxylase. Autolysis and bacterial proteolysis accelerate the release of free histidine from fish muscle proteins for action by the bacterial histidine decarboxylase to produce histamine (Stratton and Taylor 1991). However, the minimum histidine concentration required for bacterial histidine decarboxylase activity was estimated to be $100-200 \mathrm{mg} / 100 \mathrm{~g}$ (Chen et al. 1989). Therefore, the white muscle of flying fish containing free histidine at a level of $423.9 \mathrm{mg} / 100 \mathrm{~g}$ may become a vehicle for scombroid poisoning if it is contaminated with histamine-forming bacteria.

Bacterial counts, TVBN and histamine formation by S. xylosus in flying fish muscle during storage at $4-35^{\circ} \mathrm{C}$

Staphylococcus xylosus grew rapidly in flying fish meats stored at $35^{\circ} \mathrm{C}$. The bacterial levels increased to 9.0 $\log \mathrm{CFU} / \mathrm{g}$ after $24 \mathrm{~h}$ and to $9.2 \mathrm{log} \mathrm{CFU} / \mathrm{g}$ after $48 \mathrm{~h}$ (Fig. 1). Similarly, S. xylosus grew well in samples stored at $25^{\circ} \mathrm{C}$ and reached $8.7 \log \mathrm{CFU} / \mathrm{g}$ after $24 \mathrm{~h}$, and $8.9 \log \mathrm{CFU} / \mathrm{g}$ after $48 \mathrm{~h}$ of storage. Determination of bacterial populations in samples stored at 25 and $35^{\circ} \mathrm{C}$ was terminated after $48 \mathrm{~h}$ of storage due to sample spoilage. The samples stored at $15^{\circ} \mathrm{C}$ supported gradual increases of the bacteria until they reached about 8.5

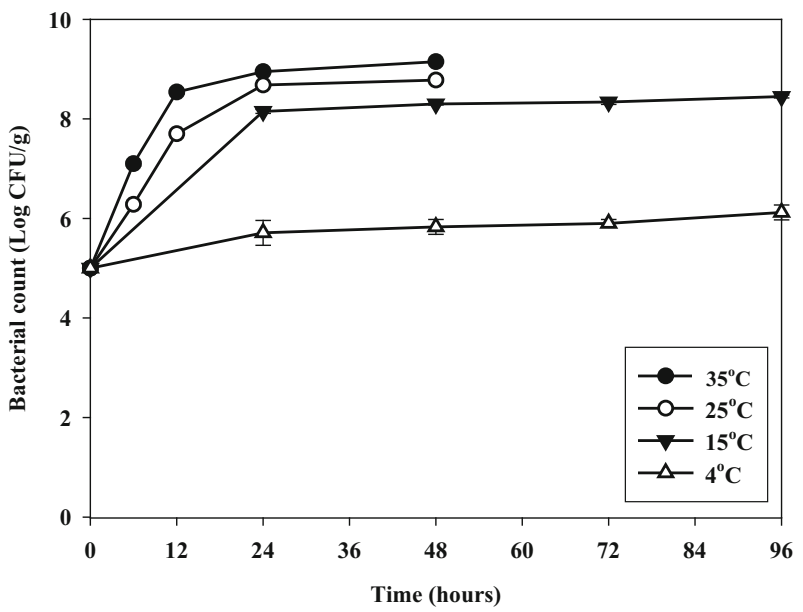

Fig. 1 Growth of Staphylococcus xylosus in minced flying fish meat inoculated with Staphylococcus xylosus at 5.0 log CFU/g during storage at $4,15,25$, and $35^{\circ} \mathrm{C}$. Each value represents the mean of three determinations \pm standard deviation 
$\log \mathrm{CFU} / \mathrm{g}$ after $96 \mathrm{~h}$. However, growth of S. xylosus was retarded in samples stored at $4^{\circ} \mathrm{C}$ up to 4 days of storage (Fig. 1). The bacterial counts stored at $35^{\circ} \mathrm{C}$ were significantly higher $(P<0.05)$ than those of samples stored at $25{ }^{\circ} \mathrm{C}$ before $12 \mathrm{~h}$. Bacterial populations in samples stored at 15,25 , and $35{ }^{\circ} \mathrm{C}$ were significantly higher $(P<0.05)$ than those of samples stored at $4{ }^{\circ} \mathrm{C}$ at all times. However, no difference was observed between the populations in samples stored at 25 and $35^{\circ} \mathrm{C}$ after $24 \mathrm{~h}$ (Fig. 1).

TVBN, including trimethylamine (TMA), dimethylamine (DMA), and ammonia $\left(\mathrm{NH}_{3}\right)$, is one of the most widely used indicators for fish quality and spoilage (Gill 1990). The levels of TVBN increased rapidly in samples during storage at $35^{\circ} \mathrm{C}$ (Fig. 2). TVBN in samples increased to $32.3 \mathrm{mg} / 100 \mathrm{~g}$ after storage at $25^{\circ} \mathrm{C}$ for $48 \mathrm{~h}$ and to $31.5 \mathrm{mg} / 100 \mathrm{~g}$ after storage at $35^{\circ} \mathrm{C}$ for $12 \mathrm{~h}$ (Fig. 2). These TVBN levels all exceeded the decomposition limit level of $30 \mathrm{mg} / 100 \mathrm{~g}$ for fish quality determination. All samples stored at $15^{\circ} \mathrm{C}$ also had levels of TVBN below $25 \mathrm{mg} / 100 \mathrm{~g}$ during storage time, reaching $22.0 \mathrm{mg} / 100 \mathrm{~g}$ in $96 \mathrm{~h}$. When stored at $4^{\circ} \mathrm{C}$, the TVBN levels only slightly increased, reaching at about $15.0 \mathrm{mg} / 100 \mathrm{~g}$ after $96 \mathrm{~h}$. According to the statistical analysis, the TVBN levels of samples at $35^{\circ} \mathrm{C}$ for the same storage time were significantly higher than those of other storage temperatures $(P<0.05)$. The following TVBN levels were observed at $25^{\circ} \mathrm{C}$ and significantly higher than those of 4 and $15^{\circ} \mathrm{C}$ storage temperatures $(P<0.05)$ (Fig. 2). The increase in TVBN is related to the formation of volatile basic components, such as $\mathrm{NH}_{3}$, TMA, and others, by enzyme autolysis and bacterial spoilage. Therefore, the elevated temperature $\left(>25^{\circ} \mathrm{C}\right)$ can increase autolytic enzyme activity and bacterial proliferation.

Similar to TVBN, the formation of histamine in samples was significantly faster in samples stored at 25 and $35^{\circ} \mathrm{C}$ than at 15 and $4^{\circ} \mathrm{C}(P<0.05$; Fig. 3). Histamine contents increased to 135 and $168 \mathrm{mg} / 100 \mathrm{~g}$ after $12 \mathrm{~h}$ of storage at 25 and $35^{\circ} \mathrm{C}$, respectively $(P<0.05)$. After $48 \mathrm{~h}$ storage, histamine contents increased rapidly to $193 \mathrm{mg} / 100 \mathrm{~g}$ at $25^{\circ} \mathrm{C}$ and $237 \mathrm{mg} / 100 \mathrm{~g}$ at $35^{\circ} \mathrm{C}$, respectively (Fig. 3). When the samples were stored at $15^{\circ} \mathrm{C}$, a low level of histamine $(80 \mathrm{mg} / 100 \mathrm{~g})$ was detected in samples after $48 \mathrm{~h}$, while a much higher level $(113 \mathrm{mg} / 100 \mathrm{~g})$ was detected in samples after $96 \mathrm{~h}$. Histamine production in samples stored at $4^{\circ} \mathrm{C}$ for $96 \mathrm{~h}$ was negligible $(<3.0 \mathrm{mg} / 100 \mathrm{~g})$. According to the statistical analysis, the histamine contents of samples at $35^{\circ} \mathrm{C}$ after 12 -h storage time were significantly higher than those of other storage temperatures $(P<0.05)$. Therefore, the optimal temperature for histamine production by S. xylosus in spiked samples was $35^{\circ} \mathrm{C}$.

The highest levels of histamine were detected after growth of S. xylosus had reached the late logarithmic phase in the samples stored at temperatures above $15^{\circ} \mathrm{C}$. This corresponded to an early observation that maximum histidine decarboxylase activity was observed during the late logarithmic phase of bacterial growth (Behling and Taylor 1982). Similarly, we previously demonstrated that high histamine contents were produced in sailfish and milkfish muscle by Enterobacter aerogenes during the late logarithmic phase of growth (Tsai et al. 2005b). However, Kim, Price, Morrissey, Field, Wei and An (2002) reported that the highest level of histamine was detected in contaminated fish muscle after $M$. morganii had reached the stationary phase of

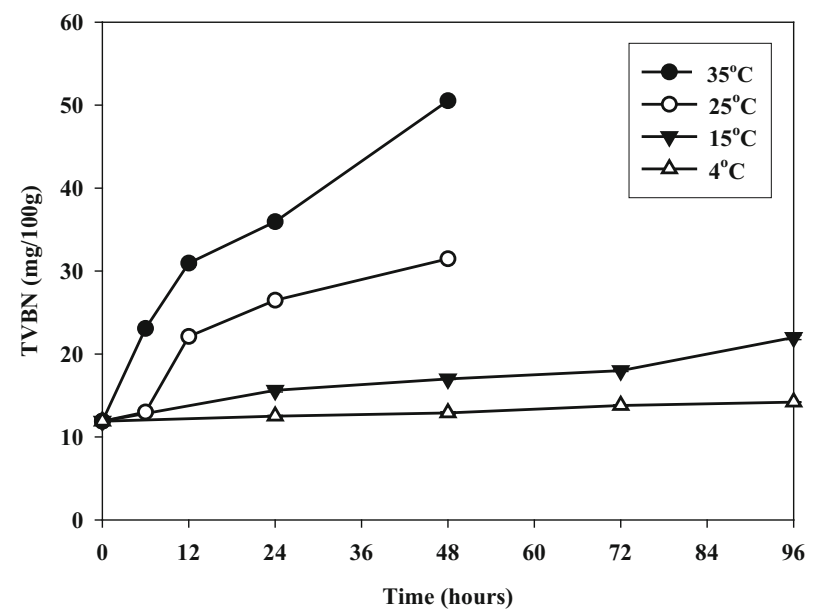

Fig. 2 Formation of TVBN in minced flying fish meat inoculated with Staphylococcus xylosus at $5.0 \log$ CFU/g during storage at $4,15,25$ and $35^{\circ} \mathrm{C}$. Each value represents the mean of three determinations \pm standard deviation 


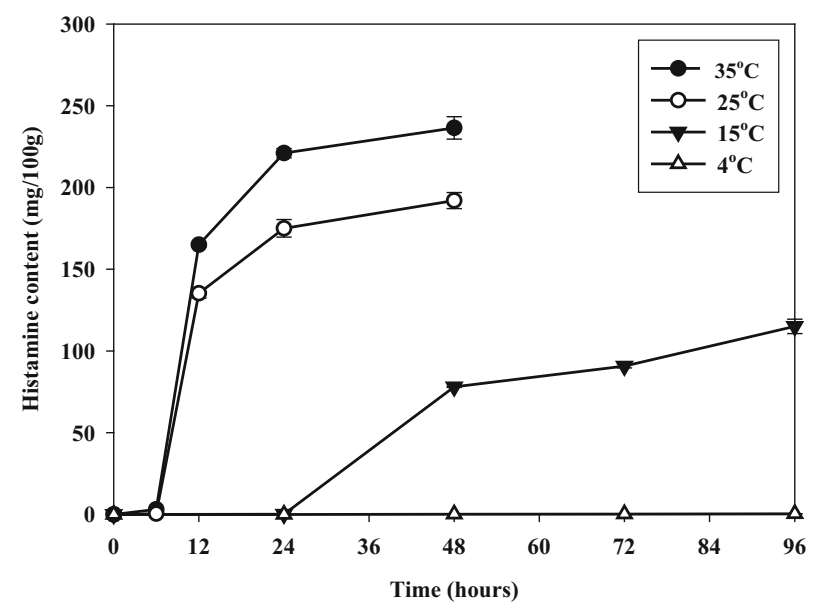

Fig. 3 Change of histamine in minced flying fish meat inoculated with Staphylococcus xylosus at $5.0 \log$ CFU/g during storage at $4,15,25$, and $35^{\circ} \mathrm{C}$. Each value represents the mean of three determinations \pm standard deviation

growth. The difference between the observations could be due to the use of different histamine producers and fish species in those studies.

The US Food and Drug Administration (FDA) has indicated that fish containing histamine at levels above $50 \mathrm{mg} / 100 \mathrm{~g}(500 \mathrm{ppm})$ should be considered a potential hazard for human health (USFDA 2001). It is important to realize that the presence of histamine in a fish does not change the color or smell of that fish, because histamine is a colorless and odorless compound (Arnold and Brown 1978). A fish with no obvious sign of spoilage may contain a high level of histamine and be consumed. When the decomposition index of TVBN contents reached the level of $30 \mathrm{mg} / 100 \mathrm{~g}$, the histamine contents had increased to higher than $168 \mathrm{mg} / 100 \mathrm{~g}$ in samples stored at 25 and $35^{\circ} \mathrm{C}$ (Figs. 2, 3). Therefore, the use of TVBN value as an indicator to predict histamine contents and risk of scombroid poisoning should be avoided. Moreover, the bacterial counts in samples stored at $4^{\circ} \mathrm{C}$ increased to $6.0 \mathrm{log}$ CFU/g after $96 \mathrm{~h}$ (Fig. 1), but low TVBN $(<15 \mathrm{mg} / 100 \mathrm{~g}$ ) and negligible histamine levels $(<3.0 \mathrm{mg} / 100 \mathrm{~g})$ were determined in samples (Figs. 2, 3). It is attributed to that low temperature $\left(4^{\circ} \mathrm{C}\right)$ can inhibit histidine decarboxylase produced by $S$. xylosus and autolytic enzyme activities in fish samples.

Recovery of $S$. xylosus in previously frozen samples during storage at $25^{\circ} \mathrm{C}$

The bacterial counts in tested flying fish meat with an initial bacterial count of $5.0 \mathrm{log}$ CFU/g during the 2 months storage at $-20^{\circ} \mathrm{C}$ were determined (data not shown). According to the statistical analysis, the bacterial count of $S$. xylosus was not statistically different during the 2 months of storage at $-20^{\circ} \mathrm{C}$ $(P>0.05)$. No histamine $(<0.05 \mathrm{mg} / 100 \mathrm{~g})$ was detected in any sample tested during the 2 months storage at $-20^{\circ} \mathrm{C}$ (data not shown). Therefore, histamine production by S. xylosus in spiked samples was effectively controlled by frozen storage at $-20^{\circ} \mathrm{C}$. Behling and Taylor (1982) and Kim et al. (2002) reported that storage of seafood at $0^{\circ} \mathrm{C}$ or below limited histamine formation to negligible levels.

Once the frozen flying fish meat stored at $-20^{\circ} \mathrm{C}$ for 2 months was thawed and then held at $25^{\circ} \mathrm{C}$, a rapid increase in S. xylosus reaching the levels of $>9.0 \mathrm{log}$ CFU/g was observed after $24 \mathrm{~h}$ (Fig. $4 \mathrm{a}$ ). The highest bacterial count of $10.0 \log \mathrm{CFU} / \mathrm{mL}$ was detected after $48 \mathrm{~h}$. The spiked samples also showed rapid increases of the contents of TVBN, reaching $25.6 \mathrm{mg} / 100 \mathrm{~g}$ in $24 \mathrm{~h}$ and $45 \mathrm{mg} / 100 \mathrm{~g}$ in $48 \mathrm{~h}$ (Fig. $4 \mathrm{~b}$ ). The TVBN contents of thawed samples stored at $25^{\circ} \mathrm{C}$ for $24 \mathrm{~h}$ and $48 \mathrm{~h}$ were significantly higher than those of spiked samples stored at $25^{\circ} \mathrm{C}$ for the same storage time (Figs. 2, $4 \mathrm{~b}$ ). The increase in TVBN is related to the formation of volatile basic components, such as ammonia, TMA, and others, by enzyme autolysis and bacterial spoilage. Therefore, the accumulation of TVBN in thawed fish arises from the release of autolytic enzymes from cells of thawed flesh and histamine-forming bacteria. Although no histamine was detected in any of the frozen flying fish samples right after thawing, it began to accumulate rapidly after $12 \mathrm{~h}$ of storage at $25^{\circ} \mathrm{C}$ (Fig. 4c). Histamine at levels of 75 and $86 \mathrm{mg} / 100 \mathrm{~g}$ was detected in samples after 24 and $48 \mathrm{~h}$ of 

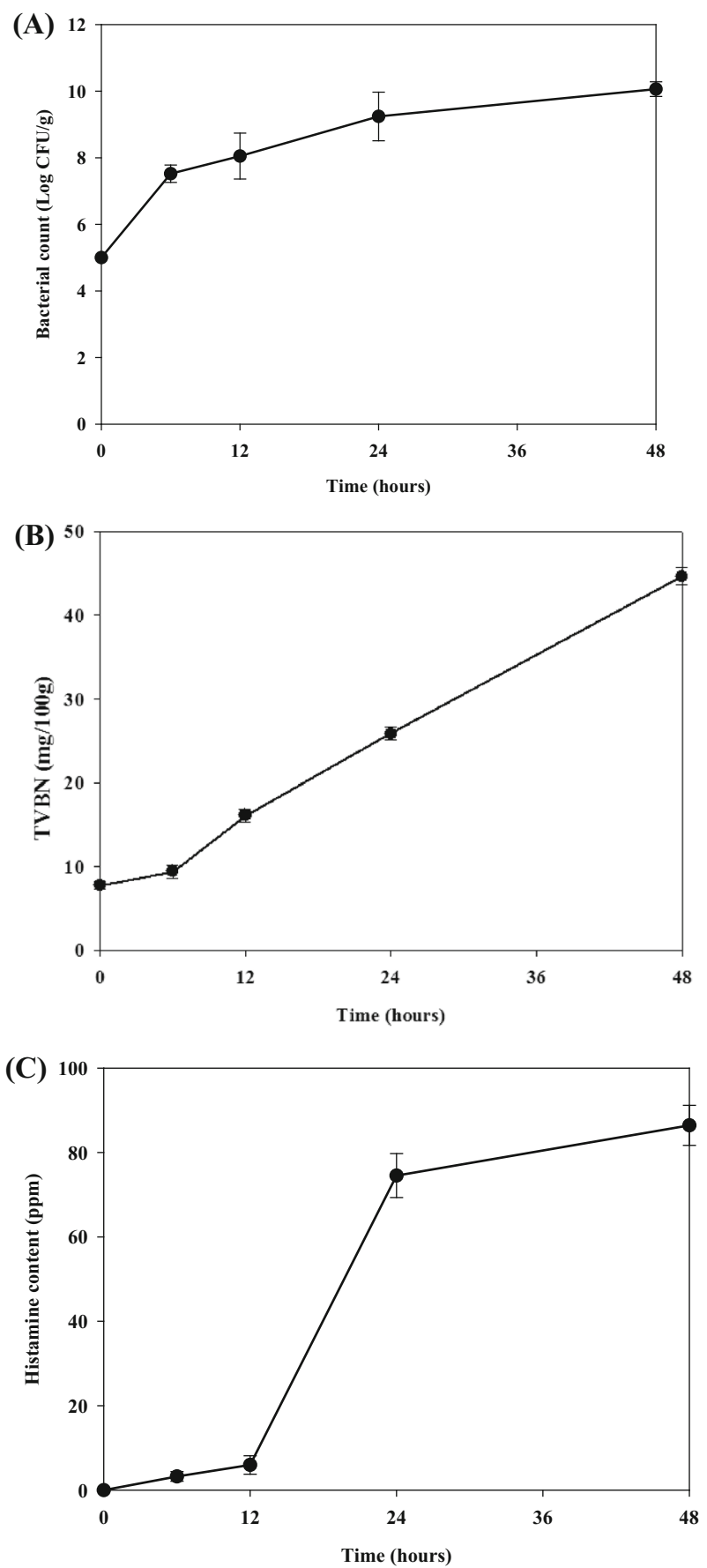

Fig. 4 Changes of bacterial counts of Staphylococcus xylosus (a), TVBN (b), and histamine content (c) in minced flying fish meat inoculated with Staphylococcus xylosus at $5.0 \mathrm{log} \mathrm{CFU} / \mathrm{g}$, stored frozen at $-20{ }^{\circ} \mathrm{C}$ for 2 months, and then thawed and stored at $25{ }^{\circ} \mathrm{C}$. Each value represents the mean of three determinations \pm standard deviation

storage at $25^{\circ} \mathrm{C}$, respectively (Fig. 4c). In this study, histamine formation was followed by bacterial proliferation in flying fish meat, when previously frozen fish was placed at $25^{\circ} \mathrm{C}$. Histamine levels in the previously frozen samples were always less than those which had not been previously frozen (Figs. 3, 4c). In this study, $S$. xylosus might be injured during freezing process. When previously frozen fish were placed at $25^{\circ} \mathrm{C}$, optimum temperature for bacterial recovery, histamine formation was followed by bacterial proliferation in the muscles. However, S. xylosus still produced hazard levels of histamine ( $>50 \mathrm{mg} / 100 \mathrm{~g}$ of fish) in thawed samples stored at $25^{\circ} \mathrm{C}$ after $24 \mathrm{~h}$. 


\section{Conclusion}

In this study, it demonstrated that hazardous levels of histamine could be formed by S. xylosus in flying fish meat when stored at temperatures above $15^{\circ} \mathrm{C}$. Flying fish may become a hazardous food if the flying fish meat is contaminated with histamine formers, such as $\mathrm{S}$. xylosus, and exposed to temperatures above $15{ }^{\circ} \mathrm{C}$. However, the formation of histamine by $S$. xylosus in samples stored at $4^{\circ} \mathrm{C}$ after $96 \mathrm{~h}$ was negligible. Although histamine was not detected in any frozen samples, it accumulated rapidly in the previously frozen flying fish meat and once thawed and stored at $25^{\circ} \mathrm{C}$. It is suggested that flying fish meat should be stored below $4{ }^{\circ} \mathrm{C}$ to control histamine production.

Acknowledgments The study was supported by the Ministry of Science and Technology, Taiwan, R.O.C. (Contract No. MOST 104-2320-B-022-001).

Open Access This article is distributed under the terms of the Creative Commons Attribution 4.0 International License (http:// creativecommons.org/licenses/by/4.0/), which permits unrestricted use, distribution, and reproduction in any medium, provided you give appropriate credit to the original author(s) and the source, provide a link to the Creative Commons license, and indicate if changes were made.

\section{References}

Abe H (1983) Distribution of free L-histidine and its related compounds in marine fishes. Bull Jpn Soc Sci Fish 49:1683-1687

Antoine FR, Wei CI, Littell RC, Marshall MR (1999) HPLC method for analysis of free amino acids in fish using o-Phthaldialdehyde precolumn derivatization. J Agric Food Chem 47:5100-5107

Antoine FR, Wei CI, Littell RC, Quinn BP, Hogle AD, Marshall MR (2001) Free amino acids in dark- and white-muscle fish as determined by o-Phthaldialdehyde precolumn derivatization. J Food Sci 66:72-77

Arnold SH, Brown W (1978) Histamine (?) toxicity from fish products. Adv Food Res 24:113-154

Behling AR, Taylor SL (1982) Bacterial histamine production as a function of temperature and time of incubation. J Food Sci 47(131-134):137

Chang SC, Kung HF, Chen HC, Lin CS, Tsai YH (2008) Determination of histamine and bacterial isolation in swordfish fillets (Xiphias gladius) implicated in a food borne poisoning. Food Control 19:16-21

Chen CM, Wei CI, Koburger JA, Marshall MR (1989) Comparison of four agar media for detection of histamine-producing bacteria in tuna. J Food Prot 52:808-813

Chen HC, Kung HF, Chen WC, Lin WF, Hwang DF, Lee YC, Tsai YH (2008) Determination of histamine and histamine-forming bacteria in tuna dumpling implicated in a food-borne poisoning. Food Chem 106:612-618

Chen HC, Huang YR, Hsu HH, Lin CS, Chen WC, Lin CM, Tsai YH (2010) Determination of histamine and biogenic amines in fish cubes (Tetrapturus angustirostris) implicated in a food borne poisoning. Food Control 21:13-18

Cobb BF, Alaniz I, Thompson CA (1973) Biochemical and microbial studies on shrimp: volatile nitrogen and amino nitrogen analysis. J Food Sci 38:431-435

Gill TA (1990) Objective analysis of seafood quality. Food Rev Int 6:681-714

Hibiki S, Simidu W (1959) Studies on the putrefaction of aquatic products-27. Inhibition of histamine formation in spoiling of cooked fish and histidine content in various fishes. Bull Jpn Soc Sci Fish 24:916-919

Hsu HH, Chuang TC, Lin HC, Huang YR, Lin CM, Kung HF, Tsai YH (2009) Histamine content and histamine-forming bacteria in dried milkfish (Chanos chanos) products. Food Chem 114:933-938

Huang MH, Ou CH (2012) A discussion of management disputes arising from the multiple utilization of flying fish resources in Taiwan and suggested countermeasures. Mar Policy 36:512-519

Hungerford JM (2010) Scombroid poisoning: a review. Toxicon 56:231-243

Kim SH, Price RJ, Morrissey MT, Field KG, Wei CI, An H (2002) Histamine production by Morganella morganii in mackerel, albacore, mahi-mahi, and salmon at various storage temperatures. J Food Sci 67:1522-1528

Konosu S, Watanabe K, Shimizu T (1974) Distribution of nitrogenous constituents in the muscle extracts of eight species of fish. Nippon Suisan Gakk 40:909-914

Kung HF, Huang CY, Lin CM, Liaw LH, Lee YC, Tsai YH (2015) The histamine content of dried flying fish products in Taiwan and the isolation of halotolerant histamine-forming bacteria. J Food Drug Anal 23:335-342

Lee YC, Kung HF, Wu CH, Hsu HM, Chen HC, Huang TC, Tsai YH (2016) Determination of histamine in milkfish stick implicated in a foodborne poisoning. J Food Drug Anal 24:63-71

Lehane L, Olley J (2000) Histamine fish poisoning revisited. Int J Food Microbiol 58:1-37

Ozogul F, Polat A, Ozogul Y (2004) The effect of modified atmosphere packaging and vacuum packaging on chemical, sensory and microbiological changes of sardines (Sardina pilchardus). Food Chem 85:49-57

Rawles DD, Flick GJ, Martin RE (1996) Biogenic amines in fish and shellfish. Adv Food Nutr Res 39:329-365

Stratton JE, Taylor SL (1991) Scombroid poisoning. In: Kvenberg JE (ed) Microbiology of marine food products, 2nd edn. AVI Publishing, New York, pp 331-351

Taylor SL (1986) Histamine food poisoning: toxicology and clinical aspects. Crit Rev Toxicol 17:91-117 
Tsai YH, Chang SC, Kung HF, Wei CI, Hwang DF (2005a) Histamine production by Enterobacter aerogenes in sailfish and milkfish at various storage temperatures. J Food Prot 68:1690-1695

Tsai YH, Kung HF, Lee TM, Chen HC, Chou SS, Wei CI, Hwang DF (2005b) Determination of histamine in canned mackerel implicated in a food born poisoning. Food Control 16:579-585

USFDA (U.S. Food and Drug Administration) (2001) Chapter 7. Scombrotoxin (histamine) formation. In: Fish and fishery products hazards and controls guide. 3rd ed. Department of Health and Human Services, Public Health Service, Food and Drug Administration, Center for Food Safety and Applied Nutrition, Office of Seafood. Washington, DC, pp 73-93

Vaaler GL, Brasch MA, Snell EE (1986) Pyridoxal 5'-phosphate-dependent histidine decarboxylase. J Biol Chem 261:11010-11014

van Poelje PD, Snell EE (1990) Pyruvoyl-dependent enzymes. Annu Rev Biochem 59:29-59 